\title{
Weed Management in Mature Coconut Plantations in Sri Lanka
}

\author{
S. H. S. Senarathne and H. A. J. Gunathilake \\ Agronomy Division, Coconut Research Institute, Lunuwila, Sri Lanka
}

\begin{abstract}
Weeds are a perennial problem in coconut plantations and cause significant losses in terms of nut yield. The occurrence of a wide range of weeds also causes difficulties in their eradication. The influence of buffalo grazing on weed biomass and nut yield was evaluated to determine the economical and effectiveness of this method to control weeds in coconut plantations in the low country wet zone of Sri Lanka. Treatments imposed were: tractor slashing as control (T1), cover cropping with Pueraria phaseoloides (T2) and buffalo grazing (T3). Slashing treatment was applied three times per year and buffalo grazing was practiced once a month to control grasses and weeds. The treatments were arranged in a Randomized Complete Block Design with three replicates. Based on the reduction of the weed biomass, treatments $\mathrm{T} 2$ and $\mathrm{T} 3$ were found to be significantly effective $(\mathrm{P}<0.05)$ over slashing treatment. Coconut yield was increased significantly $(\mathrm{P}<0.05)$ in buffalo grazing plots and decreased in cover cropping plots. Control of weeds with buffalo grazing and cover cropping with Pueraria resulted in 7\% increase and 6\% decrease in nut yield over the slashing plots respectively. Buffalo grazing was found to be the most effective method of controlling weeds in coconut plantations. Cover cropping with Pueraria phaseoloides was effective in controlling weeds in the long term, but was not economically beneficial compared with the buffalo grazing. Establishment of cover crop was helpful to conserve soil moisture but it appeared to compete with palms for soil nutrients. A high soil penetrometer resistance in the grazing plots pointed to a significant change in the soil structure as a result of buffalo traffic in the area. Harrowing the buffalo grazing plots appeared to be the best method to overcome soil compaction and finally increase soil aeration and create more favorable environment for palm growth.
\end{abstract}

Key words: cover cropping, buffalo grazing, weed management

\section{INTRODUCTION}

Coconut is a tropical perennial plantation crop and its canopy structure requires a wide spacing between palms, which permits abundant sunlight to the understory. As a result, the unutilized space beneath the plantation becomes invaded by a wide range of perennial 
and annual weed or grass species. Such weeds invariably compete with coconut for soil moisture and nutrients, affecting its growth and yield and obstructing routine estate practices (Senarathne et al., 2003). Management of the understory weed growth is, therefore, considered an essential step in maintaining the plantation. The cost of weeding $(20 \%$ of the total cost of production of the estate) accounts for a substantial proportion of the total recurrent expenditure for maintenance. Therefore, weeds in coconut plantations in Sri Lanka not only reduce nut yield due to crop weed competition but also add to the production cost. Therefore, there is an acute need to introduce effective and economically viable ground cover management for coconut plantations in Sri Lanka. Weeds in coconut plantations are managed in different ways, under the broad categories of mechanical, chemical and cultural methods (Liyanage and Liyanage, 1989). However, complete eradication of weeds is not expected and weeds have to be managed to some extent so that they do not compete with coconut.

Traditionally, coconut growers used ruminants as "sweepers" or "brushers" to keep the grass and weeds short and thus prevent nutrient and moisture competition between two crops (Reynolds, 1988). However cattle grazing can increase soil compaction which in turn adversely affects palm growth thereby diminishing total productivity of the system (Bezkorowajnyj et al., 1993). Few growers have managed coconuts and cattle together in an attempt to optimize the productivity of the system as a whole. The establishment and maintenance of a good herbaceous ground cover in the coconut understorey can provide livestock feed, while preventing the invasion of nonnutritious, yet aggressively competitive weeds. A healthy ground cover can also reduce soil erosion and increase rainwater infiltration and storage and thus the availability of water to the entire system. It's true that pasture plants usually deplete soil moisture for a period shortly after their establishment. Then average soil moisture content rise above previous levels because of reduced runoff and greater infiltration by the cover crop (Plucknett, 1974). Some leguminous forage plants used as cover crops tend to climb trees therefore; they need to be frequently cut back. The labour cost involved in this activity can be eliminated if the cover crop is grazed.

The role of animal component in the coconut farming system has not been adequately researched. Hence, an experiment was conducted in a coconut farming system with the objective of determining the effect of incorporating the buffalos on ground cover or weed management, physical properties of the soil and, nut production of coconut palm.

\section{MATERIALS AND METHODS}

The experiment was carried out at the Sub Research Station, Makandura, in the Low Country Intermediate Zone of North Western Province of Sri Lanka from January, 1999 to December 2003. The station is located at 070 19' south latitude, 790 59' west mean longitudes, at $20 \mathrm{~m}$ above mean sea level in a moist humid tropical ecosystem. The area is characterized by bi-modal pattern of rainfall with an annual mean precipitation of $1500 \mathrm{~mm}$. Approximately, 65\% of the annual rainfall is received from September 
to February (Maha). There is a smaller peak of rainfall from March to May (Yala), but the rainfall is erratic. Higher ambient air and soil temperatures (about $28 \mathrm{C} 0-32 \mathrm{C} 0$ ) and bright sunshine hours (about $6-8 \mathrm{~h} /$ day) are more common especially during the dry periods from May to September.

The soil at the site was an aluvial deep $(>120 \mathrm{~cm})$ and well to moderately drained. Surface soil dark grayish brown with a sandy loam texture. Reaction of the soil was slightly acidic (pH $6.0-6.5$ ) throughout the soil profile (Mapa et al., 2005). The trial was established under 16 year-old coconut plantation which was regularly fertilized with $3 \mathrm{~kg}$ of Adult Palm Mixture (800g Urea, 600g Rock Phosphate and $1600 \mathrm{~g}$ Muriate of Potash) per palm per year with $1 \mathrm{~kg}$ of Dolomite. Major weed species in this site were: Chloris barbata, Chromoleana odorata, Mimosa pudica, Urena lobata, Croton hirtus, Allmania nodiflora, Mitracarpus villosus, Tephrosia purpurea, Tridax procumbens, Sida acuta, Scoparia dulisis, Stachytarpheta jamaicensis and Hyptis suaveolens.

Three treatments viz: T1-tractor slashing (once in four month) (Control), T2-cover cropping with Puereria phasioloides, T3- buffalo grazing (rotation way) and 3 animals time-1 plot-1, were imposed in a Randomized Complete Block Design with three replicates. Each plot had 16 effective coconut palms. (Coconut spacing triangular planting system into $8.2 \mathrm{~m}$ $\mathrm{x} 8.2 \mathrm{~m}$ ). Treatments were applied according to a specific schedule to control of weeds. The buffalos (average body weight $400 \mathrm{~kg}$ ) were allowed to graze the plots at monthly intervals and tractor slashing was done at the latter part of the rain season at four monthly intervals which was the general practice to control weeds in this estate. The grazing plots were harrowed to improve the physical conditions of the soil at six months interval. The cover crop was established in harrowed plots to control weeds at a seed rate of $5 \mathrm{~kg} / \mathrm{ha}$. Over grown conditions of cover crop was managed to overcome competition by tractor harrowing.

Weed biomass : The weed biomass was collected from $1 \mathrm{~m} 2$ quadrates from four random points per plot every three months. Weed biomass samples were dried at $80 \mathrm{C}^{0}$ for five days to constant weight from January 1999 to December 2003.

Soil compaction : The degree of soil compaction which is an indication of resistance to root penetration was examined using a Cone Penetrometer (Penetrograh STIBOKA, The Netherlands) as described by Bradford (1986). Penetrometer readings were taken from 20 random points per plot before harrowing the grazing plots. Estimation of soil compaction value was obtained by summing the each point values. Measurements were taken in the dry period to minimize the error according to the different antecedent moisture levels.

Coconut Yield : Nut yield was taken at two monthly intervals and the total nut production per palm per year was calculated.

Data was subjected to Analysis of Variance (ANOVA) and means were separated by Least Significant Means test $(\mathrm{P}=0.05)$. The statistical program was the Statistical Analysis System (SAS, 1999). 


\section{RESULTS AND DISCUSSION}

Effect of treatments on ground cover biomass

The lowest weed biomass was recorded in plots with the cover crop Pueraria phaseoloides (Fig. 1). P. phaseoloides took several months to establish a good cover. The weed biomass was high at the initial stages in cover cropped plots which declined gradually with time. The slashing treatment suppressed weed growth for few months, but subsequently faster regrowth was observed in monocot weeds than in dicotyledonous weeds. Generally, slashing damage the aerial parts of weeds but with no physical damage to the root system or under ground plant parts such as stolen and rhizomes of the monocotyledonous weeds (Senarathne and Costa, 2009).

Thus during favorable weather, underground plant parts of some weed species produce new shoots or new flushes. For, example, the monocotyledonous weeds, Imperata cylindrica, Panicum maximum and Cynodon dactylon and several dicotyledonous weeds, Lantana camara and Chromolena odorata produced a new flush within a few weeks of slashing (Senarathne et al., 2003).

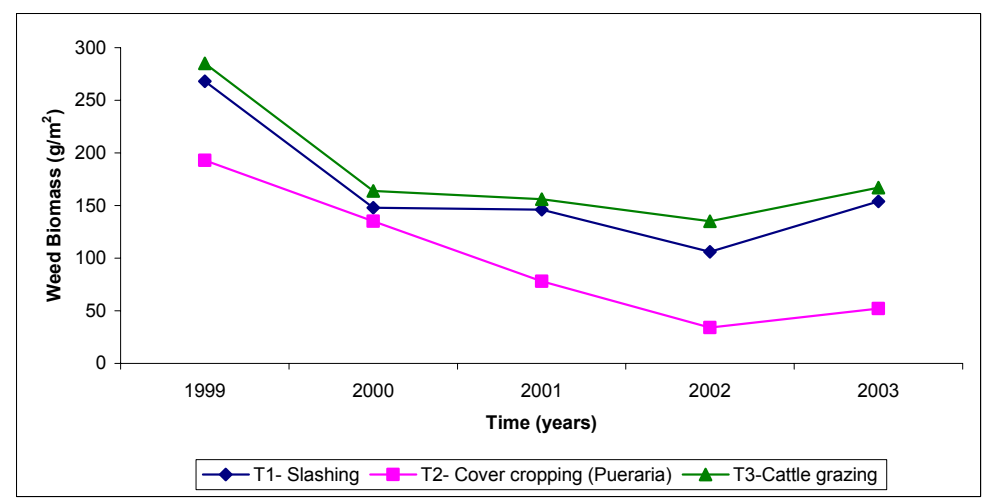

Fig. 1: Average weed biomass $\left(\mathrm{g} / \mathrm{m}^{2}\right)$ in three different practices between 1999 and 2003.

Olaoye (1977) found that slashing of Chromolena odorata caused rapid regeneration. The highest weed biomass was recorded in buffalo grazing plots but selective grazing was the major problem in this method. In this situation some weed species become dominant. There was a significant difference $(\mathrm{P}>0.05)$ between the amount of weed biomass production of slashing and buffalo grazing treatments during the experimental period. However, use of buffaloes to control understory weeds in mature coconut plantations was more economical than manual weeding (Osborne, 1972).

\section{Effect of treatments on soil compaction}

The penetrometer resistance in relation to different weed management methods is shown in Table 1. From the second year of treatment application, the penetrometer resistance in soils of the buffalo grazing plots were significantly 
higher than that of the cover crop and tractor slashed plots. The lowest resistance (110 and $108.4 \mathrm{~N} / \mathrm{m} 3$ ) was observed in the cover cropping plots in 2002 and 2003. The increased soil compaction from buffalo grazing will decrease the soil porosity, as larger pores are compressed, resulting in lowered soil water infiltration rates (Myhr et al., 1990), impeded plant root system growth, increased activity of soil denitrifiers (German and Jacques, 1990) and subsequently, all these factors contribute to the adverse effect on plant growth (Ferrero, 1991). By the end of the experiment in 2002, great soil compaction was noted in the buffalo grazing treatments. However, due to the practicing of harrowing at every 6 months enhanced soil physical conditions irrespective to soil compaction. The harrowing also lead to improve the mixing of soil nutrients of the top soils with sub soils and also increase the soil microbial activity.

Table 1: Effect of buffalo grazing, cover cropping and slashing on soil compaction

\begin{tabular}{|c|c|c|c|c|c|}
\hline \multirow{2}{*}{ Treatments } & \multicolumn{5}{|c|}{ Soil compaction $\left(\mathrm{N} / \mathrm{cm}^{3}\right)$} \\
\hline & 1999 & 2000 & 2001 & 2002 & 2003 \\
\hline $\mathrm{T}_{1 .-}$ Tractor slashing (control) & 106.4 & 108.3 & 143.1 & 138.0 & 127.3 \\
\hline $\mathrm{T}_{2 .-}$ Cover cropping (Pueraria) & 117.1 & 116.6 & 117.0 & 110.0 & 108.4 \\
\hline $\mathrm{T}_{3 .-}$ - Buffalo grazing & 112.5 & 138.7 & 172.0 & 181.4 & 183.5 \\
\hline $\operatorname{LSD}(\mathrm{P}=0.05)$ & ns & 11.3 & 11.0 & 20.2 & 18.6 \\
\hline
\end{tabular}

* ns: not significant

\section{Effect on coconut yield}

Buffalo grazing significantly increased $(\mathrm{P}<0.05)$ the nut yield of coconut over other two treatments (Table 2). This increase in nut yield commenced from the third year after application of all treatments and the trend was continued. This could be explained in terms of reduced competition for soil moisture due to lower ground cover density and increased plant nutrient content in soils due to animal dung compared to other two treatments. 
Table 2: Effect of buffalo grazing, cover cropping and slashing on nut yield

\begin{tabular}{|l|c|c|c|c|c|c|}
\hline \multirow{2}{*}{ Treatments } & \multicolumn{5}{|c|}{ Coconut yield (nuts/palm/year) } & \multirow{2}{*}{$\begin{array}{c}\text { Cumulative } \\
\text { average } \\
\text { yield }\end{array}$} \\
\cline { 2 - 6 } & $\mathbf{1 9 9 9}$ & $\mathbf{2 0 0 0}$ & $\mathbf{2 0 0 1}$ & $\mathbf{2 0 0 2}$ & $\mathbf{2 0 0 3}$ & \\
\hline $\mathrm{T}_{1}$ - Tractor slashing (control) & 64 & 89 & 81 & 65 & 91 & 78 \\
$\mathrm{~T}_{2}$-Cover cropping (Pueraria) & 57 & 81 & 76 & 51 & 93 & $72(-06)$ \\
$\mathrm{T}_{3}$ - Buffalo grazing & 66 & 94 & 86 & 69 & 112 & $85(+07)$ \\
& & & & & & \\
LSD (P=0.05) & $\mathrm{ns}$ & $\mathrm{ns}$ & $\mathrm{ns}$ & 6 & 13 & \\
\hline
\end{tabular}

(Values in parentheses are the percentage increase of nut yield over the tractor slashing treatment (control))

According to Alevalo et al., (1998) livestock grazing plays an important role in soil nutrient dynamics as it affects quantity of litter production and its nutrient composition, and nutrient cycling as a result of returns through urine and excretion. Creeping legumes like Pueraria have the additional potential of bringing in sustainable quantities of atmospheric nitrogen and improve soil fertility (Lehmann et al., 1999). Although cover crops control weeds, they are also expected to compete with coconut for soil nutrients and water, the most critical factors of growth and yield of coconut. To overcome this situation the cover crops should be managed. Unmanaged cover cropping may not produce the desired outcome of weed control, but fails to improve coconut yield. Control of weeds with slashing did not produce any yield increase in coconut. This might be a result of the presence of competition by weeds for nutrient and soil moisture.

\section{Cost/benefit analysis of different weed control methods under coconut}

The cost of different weed control practices are shown in Table 3. Benefits were calculated as the average incremental yield per year over the tractor slashing treatment (control). When calculating the cost benefit ratio, only the nut yield improvement was considered. The highest nut yield was achieved with buffalo grazing. The highest return to investment $(\mathrm{B} / \mathrm{C}$ ratio of 1.86) was given by the buffalo grazing treatment. Therefore, the most cost effective method of controlling ground cover vegetation in the present study was buffalo grazing. In this regard, buffalos play a vital role by producing organic manures and milk, in addition to income of selling calves. 
Table 3: Cost and benefit analysis of different weed control practices

\begin{tabular}{|l|c|c|c|c|}
\hline \multicolumn{1}{|c|}{ Treatment } & $\begin{array}{c}\text { Treatment } \\
\text { application } \\
\text { cost (SL Rs } \\
\text { ha }^{-1} \text { year }^{-1} \text { ) }\end{array}$ & $\begin{array}{c}\text { Average } \\
\text { annual } \\
\text { incremental }_{\text {yield ha }^{-1}}\end{array}$ & $\begin{array}{c}\text { Incremental } \\
\text { benefits (SL } \\
\text { Rs), (SL Rs } \\
\mathbf{2 0} / \mathbf{n u t})\end{array}$ & $\begin{array}{c}\text { Non } \\
\text { discounted } \\
\text { B/C ratio }\end{array}$ \\
\hline $\mathrm{T}_{1}$. Tractor slashing (control) & 10000 & - & - & - \\
$\mathrm{T}_{2}$. Cover cropping (Pueraria) & 9500 & -960 & -19200 & \\
$\mathrm{~T}_{3}$. Buffalo grazing & 12000 & 1120 & +22400 & 1.86 \\
\hline
\end{tabular}

Average labour wage SL Rs 400 day $^{-1}$

US $1 \$=$ Sri Lankan Rs. 115

\section{CONCLUSION}

The buffalo grazing produced the best costeffective treatment for the control of weeds in coconut plantations. This method is very promising with regard to increasing the land use efficiency and productivity. Supply of organic manure in situ is another advantage of buffalo grazing which can supplement inorganic fertilizer applied to coconut palm and, thereby reducing the cost of production and increasing profit margin. Practice of harrowing is suggested at three monthly intervals and it could play an important role in developing a favorable soil structure and improving the soil fertility in grazing plots. Although, cover cropping with Pueraria reduced weed density, it was less a viable option than slashing and buffalo grazing.

\section{REFERENCES}

Alevalo, L.A., Alegre, J.C., Bandy, D.E. and Szott, L.T. (1998). The effect of cattle grazing on soil physical and chemical properties in a silvopastoral system in the Peruvian Amazon, Agrof. Syst., 40: 109124.
Bezkorowajnyj, P.G, Gordon, A.M., and Mcbride, R.A. 1993. The effect of cattle foot taffic on soil compaction in a silvopastoral system. Agrof. Syst., 21: 1-10.

Bradford, J.M.(1986). The penetration resistance in a soil with well-defined structural units. Soil Sci. Am. J.44: 601-605.

Ferrero, A.F. (1991). Effect of compaction simulating cattle trampling on soil physical characteristic in woodland, Soil and Tillage Res., 19: 319-329.

German,J.C. and Jacques, D.(1990). Denitrifying activity measurements by soil core method: Effect of depth and characterization of $\mathrm{N} 2 \mathrm{O} /$ N2 ratio in different soils. Mtteilungen der Deutchen Bodenkundlichen Gesellschaft. Proc. Int. Workshop on Denitrification. Soil, Rhizoshere and Aquifer, Giessen, FRG, March 17-19,1989.

Lehmann, J., da Silva, J.P., Steiner, C., Nehls, T., Zech, W. and Glaser B. (1999) Nutrient availability and leaching in an archaeological Anthrosol and a Ferralsol of the Central Amazon basin: fertilizer, manure and charcoal amendments. Plant Soil, 249:343-357 
Liyanage, L.V.K. and de Liyanage, M.S. (1989). Weed control under-story weed management in coconut lands. CORD, 1: 48-56.

Mapa R.B., Dasanayake A.R. and Nayakekorale H.B. (2005). Soils of the Intermediate Zone of Sri Lanka, Special Publication, Soil Science Society of Sri Lanka, 70-95.

Myhr K. Haland A. and Nesheim L. (1990). The effect of wet composted and untreated cattle slurry, and of soil compaction, on water infiltration rates in cultivated soils. Norsk Landbruksforsking 4(3): 161-172.

Olaoye, S.O.A. (1977). The effect of slashing on the performance of Eupatorium odoratum in Nigeria. Proc. $7^{\text {th }}$ Nigerian Weed Sci. Conf. (Abuja, Nigeria, 5-8 March 1977). S.M. Publishers, Abuja, 23-28.

Osborne, H.G. (1972). Cattle production and management under coconut (ed: E. Hugh) South Pacific Commission, New Caledonia, 141-144.

Plucknett, D.L. (1974). Managing pasture and cattle under coconuts. West view Tropical Agriculture Series 2. Boulder, Co (USA): West view Press

Reynolds, S.G. (1988). Pastures and cattle under coconuts. FAO Plant Protection and Production Paper 91. Rome: FAO

Statistical Analysis Systems 1999. SAS 1, STAT Users Guide, Release, 7.00. Statistical Analysis Systems Institute, Cary, 1028.
Senarathne, S.H.S and Costa, M.J.I. (2009). Comparison of several recommended cultural practices for weed management and their effects on yield of coconut in tropical coconut plantations, Proc. 8th Workshop of the EWRS Working Group: Physical and Cultural Weed Control conf., Zaragoza, Spain, 17-23

Senarathne S.H.S., Samarajeewa, A.D. and Pererea, K.C.P. (2003). Comparison of different weed management systems and their effects on yield of coconut plantations in Sri Lanka. Weed Biol. and Managt. 3: 158-162

Vergara, N.T. and Nair, P.K.R. (1985). Agro forestry in the South Pacific region: An overview. Agrof. Syst.. 3: 363-379. 